УДК $339.56+664.76$

DOI: $10.15673 /$ fie.v10i2.955

\author{
Нікішина О.В. \\ доктор економічних наук, старший науковий співробітник \\ E-mail:ksenkych@gmail.com \\ Зарудна 0.П. \\ аспірант \\ відділ ринкових механізмів та структур \\ Інститут проблем ринку та економіко-екологічних досліджень НАН України \\ Французький бульвар, 29, м. Одеса, Україна, 65044 \\ E-mail: zarudnayaolya@ukr.net
}

\title{
ГЛОКАЛІЗАЦІЯ ТОВАРНИХ РИНКІВ: ТЕОРЕТИЧНІ Й ПРИКЛАДНІ АСПЕКТИ
}

\begin{abstract}
У статті шляхом декомпозиції та аналізу компонентів категорії «ринкова глокалізація» визначено іï природу, форми та концептуальну сутність, обґрунтовано доцільність використання даної дефрініції в сучасних ринкових дослідженнях для оцінки динамічних процесів синтезу локалізації й глобалізації товарних ринків. Показано взаємозв'язок глокалізації з процесами ринкової інтеграції та дезінтеграції, в основу яких покладено принцип об'єднання (декомпозиції) товарно-фрінансово-інфоормаційних потоків суб'єктів за ланками логістичного ланцюга. Виділено дві форми ринкової глокалізації, досліджено ії сучасні тенденції на прикладі ринків зернових і хлібних продуктів. Акцентовано увагу на необхідності збалансування внутрішнього й зовнішнього векторів інтеграційної політики держави $з$ цільовою орієнтацією на нарощування обсягів експорту продуктів зернопереробки з високою доданою вартістю, підвищення їх якості, зменшення рівня «тінізації» хлібного ринку шляхом інституційних трансформацій.

Ключові слова: локалізація, товарний ринок, інтеграція, глокалізація, зернові і хлібні продукти, експорт, інтеграційна політика держави.
\end{abstract}

This work is licensed under a Creative Commons Attribution 4.0 International License http://creativecommons.org/licenses/by/4.0/

Постановка проблеми та її зв'язок з важливими науковими та практичними завданнями. Розвиток сучасних економічних систем характеризується одночасно двома протидіючими тенденціями: глобалізацією та локалізацією ринків. Локалізація ринків базується на критерії мінімізації витрат обігу, на відміну від глобалізації, що грунтується на критерії мінімізації витрат виробництва одиниці продукції за рахунок ефекту масштабу [1, с. 257]. Результатом їх взаємодії та синтезу постає процес глокалізації, який $є$ однією із характеристик постіндустріальної економіки. Дослідження сучасних тенденцій глокалізації в контексті її трансформаційного впливу на інтеграційний розвиток стратегічних товарних ринків, зокрема, зернових і хлібних продуктів, має важливе значення для обгрунтування пріоритетів державної інтеграційної політики, нейтралізації ризиків зовнішньоекономічній і продовольчій безпеці, розробки експортної стратегії суб'єктів господарювання, що актуалізує доцільність нових розробок у даному науковому напрямі.

Аналіз останніх публікацій по проблемі. Питанням дослідження концептуальної сутності категорії «глокалізація» присвячені праці Р. Робертсона [2], Х. Ходкера [3], Е. Гіддеса [4] та інших іноземних учених. «Універсалізація партикуляризації й парти- куляризація універсалізації», - таке визначення дефініції дає соціолог Р. Робертсон [2]. У своїй праці Х. Ходкер доводить, що глокалізація синтезує процеси макролокалізації й мікроглобалізації [3]. У працях вітчизняних учених процеси глокалізації залишаються маловивченими, водночас з'являються нові розробки. Так, Т. О. Осташко і В. Е. Лір відзначають, що «Глокалізація стає невід'ємною ознакою сучасних інтеграційних процесів» [4, с. 58]. До досліджень вказаного напряму долучилися й автори статті $[6,7]$.

Питання теоретико-методичної оцінки процесів локалізації товарних ринків висвітлені у працях В.В. Власова [8], К. В. Скімової [9], Н.В.Новікової [10], Ю. В. Пруднікова [1], А. В. Ступнікової [11] та інших економістів. Водночас поглибленого вивчення потребують питання обгрунтування теоретичної сутності процесу глокалізації у ринковому вимірі та ідентифікації сучасних проявів глокалізації ринків на базі нових емпіричних досліджень.

Формулювання цілей дослідження. Мета статті - визначення теоретичної сутності ринкової глокалізації та іï характерних рис і проявів на прикладі конкретних товарних ринків, зокрема ринків зернових і хлібних продуктів, як підгрунтя для обгрунтування пріоритетних напрямів інтеграційної політики держави з урахуванням сучасних змін глобальної 
кон'юнктури ринків.

Виклад основних результатів та їх обгрунтування. Для інтерпретації сутності категорії «глокалізація» в ринковому вимірі розглянемо природу іiі компонентів - локалізації й глобалізації товарних ринків.

Енциклопедичні ресурси визначають термін «локальний» (лат. localis - місцевий) як місцевий, притаманний тільки певному місцю; той, що не виходить за певні межі [12]. Більшість учених інтерпретують локальний ринок як частину регіонального або міжрегіонального ринку з позицій територіального підходу [8, 10]. Водночас ідентифікувати локальний ринок, спираючись лише на зовнішні (територіальні) ознаки неможливо, тому що територіальні межі можуть бути гнучкими та визначатися суб'єктами господарювання відповідно до їх цілей. Тому виникає необхідність дослідження внутрішніх ознак локального ринку, зокрема, його економічного потенціалу та відтворювальної основи. Відтворювальний підхід до визначення дефініції знаходимо в працях К. В. Скімової: локальними є ринки, в яких сфери виробництва, розподілу, обміну та споживання обмежені адміністративними межами, і які є гарантом зростання економічної незалежності регіону [9].

Авторське визначення категорії «локальний ринок» $\epsilon$ таким [6]: система економічних відносин між виробниками та споживачами товарів і послуг, що формується в певних географічних межах та має низку особливостей, притаманних певній території, зокрема, унікальний попит, відтворювальний потенціал, спільність економічних інтересів суб'єктів у їі межах, короткі сталі канали збуту продукції тощо. Дане визначення містить головні відмінні ознаки локального ринку, а саме:

1) територіальне обмеження - економічні відносини між виробниками і споживачами здійснюються в певних географічних (територіальних) межах; найчастіше в межах одного адміністративного утворення (міста, району і т.д.);

2) наявність потенціалу (відтворювальної основи) для економічної діяльності певного напряму в регіоні;

3) домінування регіональних виробників, які підтримують виробничий характер ринкових відносин;

4) унікальність споживчого попиту, сформованого на певній території, i, відповідно, унікальність регіональної структури витрат населення;

5) короткі сталі збутові канали - певні товари реалізуються безпосередньо на території їх виробництва 3 максимальним наближенням до споживача;

6) спільність економічних інтересів учасників процесу відтворення, що визначає регіональні особливості пропозиції й попиту;

7) внутрішня і зовнішня відкритість.

Важливою характеристикою локального ринку $є$ його товарна специфіка, яка визначає унікальність попиту й пропозиції певного територіального ареалу. Згідно дослідженням Е. Чемберліна, просторова диференціація попиту та пропозиції призводить до просторової диференціації ринків і до формування локальних ринків. Таким чином, різні (диференційовані) товари продаються на різних ринках [13].

Локальний ринок - це підсистема (складовий елемент) системи вищого рівня ієрархії. Локальний ринок може бути складовою регіонального, міжрегіонального, національного або глобального ринку, що свідчить про його багаторівневий характер. На думку В. В. Власова, локальний ринок у своїх межах інтегрує мезо- і макрорівні економічних відносин [8]. Між локальним і регіональним ринком існує важлива відмінність. Кордони регіональної ринкової системи $\epsilon$ чітко визначеними й закріпленими як кордони адміністративно-територіальної одиниці. Межі ж локального ринку є гнучкими; вони залежать від розвиненості транспортних мереж та величини тарифу, щільності розміщення покупців тощо. Згідно 3 позицією Пруднікова Ю. В., локальний ринок $є$ особливим елементом національної ринкової системи та об'єктом державної економічної політики (але не регіональної) [1, с. 256-257].

Локальний ринок в економічному просторі своєї території виконує такі основні функиії [6]:

1) забезпечує взаємодію виробників i їx об'єднань та споживачів у певних географічних межах, а також узгодження економічних інтересів учасників ринкового процесу відтворення;

2) визначає кількісні пропорції в структурі попиту й пропозиції, рівень рівноважних цін товарів;

3) виконує роль сигнальної системи для виробників і споживачів за допомогою прямих і зворотних зв'язків;

4) організує зв'язок між суб'єктами національних і глобальних ринків та споживачами щодо динаміки змін місцевого споживчого попиту;

5) забезпечує участь території в регіональних, міжрегіональних, національних та глобальних економічних зв'язках.

Територіальні межі локального ринку є рухомими, що знаходить прояв у взаємодії локальних ринків як між собою, так і з національним та глобальним ринками. На думку К. В. Скімової, відсутність прямого або зворотного зв'язку в функціонуванні локальних ринків призводить до автономності й сегментованості розвитку регіону. Локальні ринки можна об'єднати в систему, що є сукупністю ринкових утворень різного типу, мета яких - забезпечення ефективного розвитку регіонального процесу відтворення [9, с. 17].

Термін «глобалізаиія» (фр. global - всезагальний; такий, що охоплює усю земну кулю) енциклопедичні ресурси інтерпретують як складний, багатогранний процес, що охоплює усі сторони суспільного розвитку і втілюється у зростаючій взаємозалежності країн світу в результаті формування єдиного всесвітнього господарського простору [12]. На практиці проявами глобалізації є економічна інтеграція державних ринків у світову систему. Одним із негативних іiі наслідків $є$ посилення нерівномірності й нестабільності національного й світового економічного розвитку.

На нашу думку, термін «глокалізація» можна 
використати для характеристики сучасних процесів синтезу локалізації й глобалізації товарних ринків (рис. 1). Локалізація як процес наближення виробництва однорідних товарів до споживання у межах деякого територіального ареалу може бути наслідком як інтеграції, так і дезінтеграції елементів ринкової системи. А. В. Ступнікова розглядає локалізацію ринків як форму дезінтеграції ринкового простору [11]. Ю. В. Прудніков виділяє два напрями локалізації ринків [1, с. 257]: (1) зверху донизу, у формі поділу існуючого більш масштабного ринку на сегменти шляхом запровадження бар'єрів монопольного характеру; (2) знизу доверху, шляхом концентрації в межах певної території торговельних угод, здійснюваних розрізненими суб' єктами.

На думку авторів, ринкову інтеграцію можна інтерпретувати як процес об'єднання не тільки суб'єктів ринку, але й товарно-фінансовоінформаційних потоків за ланками виробничологістичного ланцюжка. Потоковий підхід до трактування інтеграції дозволяє дослідити взаємодію локалізації й глобалізації товарних ринків, тобто процес їх глокалізації. Початковим етапом глокалізації $\epsilon$ розширення товарних меж ринку за рахунок появи виробництва продуктів зі специфічними властивостями, що користуються попитом не тільки на локальних, але й глобальних ринках. Наступним етапом $є$ експорт даних продуктів, що, 3 одного боку, сприяє встановленню й посиленню інтеграційних зв'язків між локальним і глобальним ринками, взаємопроникненню місцевого ринку в світовий ринковий простір, 3 іншого, призводить до розширення географічних меж ринку, тобто його глокалізації.

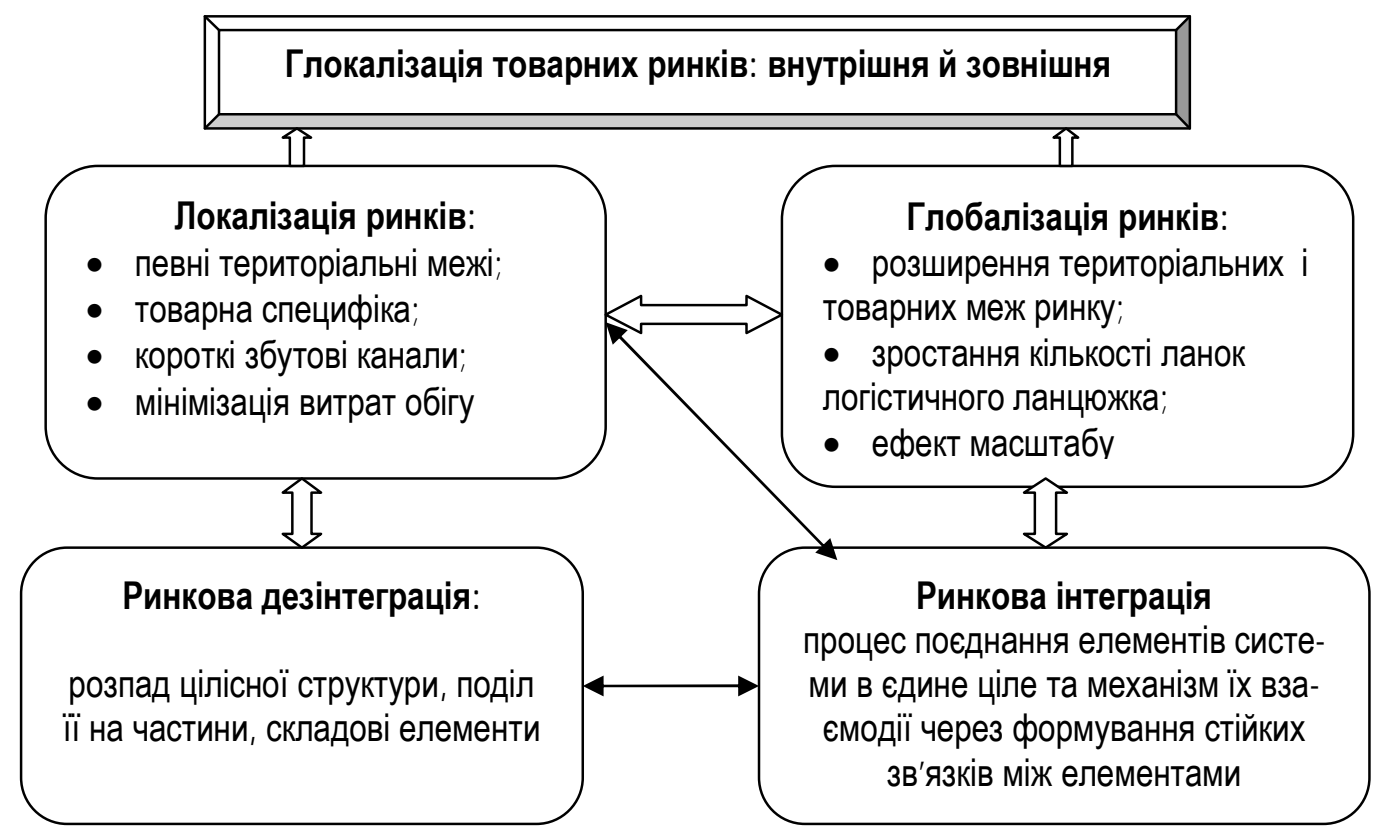

Рис. 1. Напрями взаємодії процесів локалізації й глобалізації товарних ринків* *авторська розробка

Базуючись на емпіричних дослідженнях [6, 7], пропонуємо виділити дві форми ринкової глокалізації: внутрішню й зовнішню (див. рис. 1). Внутрішня глокалізація здійснюється в географічних межах держави і пов'язана, зокрема, з міжрегіональною інтеграцією товарних ринків. Зовнішня глокалізація має міждержавний характер і орієнтована на інтеграцію місцевого ринку (регіонального або державного) до світової системи. На думку С. Ф. Авдокушина, глокалізація генерує й розвиває мережеву конкуренцію 3 прямим геоекономічним обміном між регіонами транслокальністю. Транслокальність сприяє заміщенню суперництва держав локальними взаємодіями в світовій економіці [14].

Спостереження за динамічно-структурними змінами у виробництві зернових і хлібних продуктів Одеського регіону (таблиця 1) дають можливість визначити головні компоненти формування нових тенденцій внутрішньої глокалізації або «макролокаліза- uіï». За статистичними даними, у 2016 р. Одеська область забезпечила 6,7\% валового зернового збору країни, 8,1 \% виробництва пшениці, 4,3\%, 6,8\% і $13,6 \%$ державного випуску борошна, хлібобулочних виробів та круп відповідно. Незважаючи на існуючу тенденцію скорочення обсягів регіонального виробництва борошномельної та хлібної продукції (на 64 \% і 72,3 \% в 2016 р. порівняно з 1990 р.), за аналізований період частка регіонального випуску в загальнодержавному повільно зростає (з 3 \% до 4,3\% для борошна й з 4,1 \% до 6,8 \% для хлібобулочних виробів).

Дана тенденція є наслідком, 3 одного боку, менших темпів скорочення регіонального виробництва борошна, хліба і хлібобулочних виробів (далі -

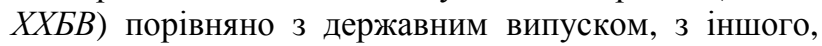
розширенням меж локального ринку за рахунок суміжних областей, тобто «макролокалізації». Обсяги круп'яного виробництва в регіоні порівняно з 1990 р. зросли в 10 разів і склали в 2016 р. 50,9 тис. т, при 
Таблиця 1

Динаміка обсягів виробництва зерна, зернових і хлібних продуктів в Одеській області, тис. тонн*

\begin{tabular}{|c|c|c|c|c|c|c|c|c|c|}
\hline \multirow{2}{*}{ Види товарів } & \multicolumn{7}{|c|}{ Роки } & \multicolumn{2}{|c|}{2016 р. у \% до: } \\
\hline & 1990 & 2005 & 2010 & 2013 & 2014 & 2015 & 2016 & 1990 & 2010 \\
\hline 1. Зернові культури & 2674 & 2669 & 2929 & 3671 & 3677 & 3489 & 4403 & 164,7 & 150,3 \\
\hline $\begin{array}{l}\text { y\% до валового збору } \\
\text { держави }\end{array}$ & 5,2 & 7,0 & 7,5 & 5,8 & 5,8 & 5,8 & 6,7 & $\mathrm{X}$ & $\mathrm{X}$ \\
\hline 1.1. Пшениця & 1652 & 1268 & 1318 & 1634 & 1848 & 1828 & 2113 & 127,9 & 160,4 \\
\hline $\begin{array}{l}\text { y\% до валового збору } \\
\text { держави }\end{array}$ & 5,4 & 6,8 & 7,8 & 7,3 & 7,7 & 6,9 & 8,1 & $X$ & $\mathrm{X}$ \\
\hline 2. Борошно & 233,0 & 147,7 & 109,5 & 111,3 & 100,8 & 107,1 & 83,9 & 36,0 & 76,6 \\
\hline $\begin{array}{l}\text { у\% до державного } \\
\text { виробництва }\end{array}$ & 3,0 & 5,0 & 4,2 & 4,3 & 4,3 & 4,9 & 4,3 & $\mathrm{X}$ & $\mathrm{X}$ \\
\hline $\begin{array}{l}\text { 3. Хліб та хлібобулочні } \\
\text { вироби }\end{array}$ & 276,0 & 107,9 & 93,9 & 82,2 & 78,3 & 80,8 & 76,5 & 27,7 & 81,4 \\
\hline $\begin{array}{l}\text { y\% до державного } \\
\text { виробницчтва }\end{array}$ & 4,1 & 4,8 & 5,2 & 5,3 & 5,8 & 6,6 & 6,8 & $X$ & $X$ \\
\hline 4. Крупи & 5,1 & 5,2 & 5,5 & 7,7 & 25,4 & 39,1 & 50,9 & y10p. & y9,3p. \\
\hline $\begin{array}{l}\text { y\% до державного } \\
\text { виробничтва }\end{array}$ & 0,5 & 1,5 & 1,6 & 2,1 & 7,3 & 10,9 & 13,6 & $\mathrm{X}$ & $\mathrm{X}$ \\
\hline
\end{tabular}

"Розраховано авторами за даними Державної служби статистики України та Головного управління статистики в Одеській області $[15,16]$

цьому частка Одеської області в загальному випуску зросла з 0,5\% до 13,6 \%, що є свідченням прискореного розвитку зернопереробної промисловості та активізації міжрегіональної ринкової інтеграції.

Вказану тенденцію підтверджує регіональна структура виробництва борошна, хлібобулочних виробів та круп в Причорноморському макрорегіоні (таблиця 2). У 2016 р. Одеська область забезпечила $47 \%$ виробництва борошна, $61 \%$ хлібної й $70 \%$ круп'яної продукції в макрорегіоні. За період 19902016 рр. частка Одеської області у випуску борошна та ХХБВ зросла на 8,1 \% і 11,3\% відповідно, у випуску круп - на $42 \%$ (порівняно 32005 р.).

Таблиця 2

Структура виробництва борошна, хліба й хлібобулочних виробів та круп в Причорноморському регіоні, \%*

\begin{tabular}{|c|c|c|c|c|c|c|c|c|}
\hline Області & 1990 & 2005 & 2010 & 2013 & 2014 & 2015 & 2016 & $\begin{array}{c}\text { Зміни }(+,-) \\
(7-1)\end{array}$ \\
\hline $\boldsymbol{A}$ & 1 & 2 & 3 & 4 & 5 & 6 & 7 & 8 \\
\hline \multicolumn{9}{|c|}{ Регіональна структура виробниитвва борошна, \% } \\
\hline 1. Одеська & 38,77 & 47,28 & 40,02 & 46,79 & 45,13 & 44,18 & 46,84 & $+8,07$ \\
\hline 2. Миколаївська & 34,11 & 25,99 & 22,77 & 16,94 & 15,27 & 18,81 & 20,15 & $-13,96$ \\
\hline 3. Херсонська & 27,12 & 26,73 & 37,21 & 36,27 & 39,60 & 37,00 & 33,01 & $+5,88$ \\
\hline $\begin{array}{l}\text { 4. Усього Причорно- } \\
\text { морський регіон, тис. т }\end{array}$ & 601,0 & 312,4 & 273,6 & 237,9 & 223,2 & 242,4 & 234,2 & $+39,0$ \\
\hline $\begin{array}{l}\text { y\% до державного ви- } \\
\text { робництва }\end{array}$ & 7,83 & 10,61 & 10,40 & 9,28 & 9,47 & 10,96 & 11,23 & $+3,4$ \\
\hline \multicolumn{9}{|c|}{ Регіональна структура виробництва хліба та хлібобулочних виробів, \% } \\
\hline 1. Одеська & 49,7 & 51,7 & 56,9 & 57,1 & 58,3 & 60,2 & 61,0 & $+11,3$ \\
\hline 2. Миколаївська & 25,4 & 24,9 & 22,3 & 21,0 & 19,9 & 19,6 & 17,9 & $-7,5$ \\
\hline 3. Херсонська & 24,9 & 23,5 & 20,8 & 21,9 & 21,8 & 20,3 & 21,1 & $-3,7$ \\
\hline $\begin{array}{l}\text { 4. Усього Причорно- } \\
\text { морський регіон, тис. т }\end{array}$ & 555,0 & 208,8 & 165,1 & 144,0 & 134,2 & 134,3 & 125,4 & $+22,6$ \\
\hline $\begin{array}{l}\text { y\% до державного ви- } \\
\text { робниитва }\end{array}$ & 8,3 & 9,2 & 9,1 & 9,2 & 9,9 & 10,9 & 11,2 & $+2,9$ \\
\hline
\end{tabular}


Продовження табл.2

\begin{tabular}{|l|c|c|c|c|c|c|c|c|}
\hline \multicolumn{8}{|c|}{ Регіональна структура виробничтва круп, \% } \\
\hline 1. Одеська & 100,0 & 28,26 & 22,92 & 20,47 & 54,43 & 69,20 & 70,14 & $-29,86$ \\
\hline 2. Миколаївська & 0,0 & 14,67 & 6,25 & 1,06 & 0,78 & 0,45 & 0,38 & 0,38 \\
\hline 3. Херсонська & 0,0 & 57,07 & 70,83 & 78,46 & 44,79 & 30,35 & 29,48 & 29,48 \\
\hline $\begin{array}{l}\mathbf{4 . ~ У с ь о г о ~ П р и ч о р н о - ~} \\
\text { морський регіон, тис. т }\end{array}$ & $\mathbf{5 , 1}$ & $\mathbf{1 8 , 4}$ & $\mathbf{2 4 , 0}$ & $\mathbf{3 7 , 6}$ & $\mathbf{4 6 , 7}$ & $\mathbf{5 6 , 5}$ & $\mathbf{7 2 , 6}$ & $\mathbf{y ~ 1 4 , 2 p .}$ \\
\hline $\begin{array}{c}\text { у\% до державного ви- } \\
\text { робничтва }\end{array}$ & 0,5 & 5,4 & 7,1 & 10,2 & 13,3 & 15,8 & 19,5 & $+19,2$ \\
\hline
\end{tabular}

* Розраховано авторами за даними Державної служби статистики України [15]

Такі структурні співвідношення свідчать про подовження каналів збуту зернових і хлібних продуктів одеських виробників, розширення меж локального ринку за рахунок суміжних областей, його гнучкість, відкритість та міжрегіональний характер. Необхідно відзначити, що Одеський ринок борошномельнокруп'яної та хлібобулочної продукції виконує стабілізуючу функцію в розвитку зернопереробної промисловості макрорегіону в кризовий період. Загалом Причорноморський регіон у 2016 р. забезпечив $11,2 \%$ загальнодержавного борошняного й хлібного виробництва, 19,5\% круп'яного виробництва, що на $3 \%$ і $19 \%$ вище показника 1990 року (див. табл. 2).

Сучасні тенденції зовнішньої глокалізащії дослідимо на прикладі українського ринку ХХБВ тривалого зберігання. Передумовою зовнішньої глокалізації державних хлібних ринків стала поява нових продуктів довготривалого зберігання, зокрема, заморожених напівфабрикатів. Існує дві групи таких товарів: (1) сирі заготовки, що не піддаються попередній випічці; (2) випечені частково вироби (заморожені або охолоджені, але готові). Першою країною, в якій стартувало виробництво замороженого хліба, майже тридцять років тому стала Франція. Головні технології виробництва цієї продукції були розроблені в США. У Європейському Союзі на частку замороженого хліба припадає майже $50 \%$ ринку; в Україні даний напрям динамічно розвивається та вважається перспективним. Рентабельність виробництва хлібобулочних виробів із заморожених напівфабрикатів $\epsilon$ не нижчою 50-60 \%, що дозволяє підвищити доходність соціально орієнтованих підприємств [18].

Завдяки методу швидкого заморожування термін зберігання товару за температури мінус $18^{\circ} \mathrm{C}$ складає 6 місяців. Подовжений термін реалізації хлібних напівфабрикатів дозволяє перевозити продукцію на великі відстані без втрати ііі якості, тобто розширює географічні межі локального ринку, сприяє його інтеграції в глобальну ринкову систему. Технологічні можливості хліба швидкого замороження дозволяють його експортувати або імпортувати. У 2016 р. Україна експортувала продукції за УКТЗЕД 19012 «Суміші та тісто для виробництва хлібобулочних виробів» на суму 1 млн. дол., що в 11 разів вище показника 2008 р.; водночас обсяги імпорту склали 3,1 млн. дол., що на $26 \%$ нижче рівня 2008 року (таблиця 3). За період 2008-2016 рр. зовнішня торгівля даною товарною групою характеризувалася від'ємним сальдо, однак його рівень знизився вдвічі (з -4,1 млн. дол. в 2008 р. до $-2,1$ млн. дол. в 2016p.).
У географічній структурі імпорту товарів за УКТЗЕД 19012 лідирують Бельгія (23,5 \% в 2016 р.), Польща $(22,2 \%)$ та Австрія $(17,6 \%)$; головним зовнішнім ринком збуту українських хлібних напівфабрикатів є Білорусь - 90,4\% [15].

Динаміка зовнішньоторговельних операцій (див. табл. 3) є наочним свідченням сировинної орієнтації українського агроекспорту: у міру збільшення ступеня переробки продукції обсяги її експорту зменшуються від 6,07 млрд. дол. для зерна до 0,14 i 0,11 млрд. дол. (2016 р.) для борошномельнокруп'яної й хлібобулочної продукції відповідно; таке ж співвідношення притаманне й для сальдо, значення якого зменшується від 2,4 млрд. дол. для зернових культур до 0,12 млрд. дол. для продуктів їх переробки. У зв'язку $з$ цим Т. О. Осташко зазначає (і ми підтримуємо цю позицію), що в умовах зміни глобальної кон'юнктури пріоритетним завданням держави стає нарощування експорту продукції 3 вищою доданою вартістю, збереження існуючих і освоєння нових зовнішніх ринків збуту вітчизняної переробної продукції $[5,19]$.

Структурні зміни у світовій торгівлі вплинули на експорт хлібобулочних і борошняних кондитерських виробів з України, обсяги якого, починаючи 3 2014 року, стрімко зменшуються. У 2016 р. експорт українських хлібопродуктів склав 111,5 млн. дол., що на $45 \%$ менше рівня 2008 р. і на $65 \%$ - рівня 2013 р. Якщо у 2008 р. частка товарної групи 1905 досягала 82,6 \% від експорту товарів підгрупи 19 «Продукти із зернових культур» і 8,1 \% від суми експорту готових харчових продуктів (група IV), то в 2016 р. iї питома вага значно зменшилася й склала $52,5 \%$ і 4,6 \% відповідно (див. табл. 3).

У натуральному виразі за 2008-2016 рр. обсяги експорту вітчизняних хлібопродуктів зменшилися на $33 \%$ і склали у звітному році 83,5 тис. т. (таблиця 4). У структурі хлібного експорту 48,6 \% припадає на товарну групу 190531 «Печиво солодке сухе», друге місце посідає товарна група 19059 «ншші вироби» із часткою 23,1\%, третє місце - товарна група 190532 «Вафлі та вафельні облатки» із часткою $17,8 \%$. За період, що аналізується, найвищі обсяги експорту були зафіксовані в 2013 р. - 161,3 тис. т. В цілому обсяги експорту хлібопродуктів тривалого зберігання складають близько $26 \%$ від обсягів їх виробництва. Головні зовнішні ринки збуту українських хлібопродуктів знаходяться в Казахстані (14,6\% в 2016 р.), Молдові $(11,1 \%)$ та Білорусі $(10,4 \%)$ [15]. 
Таблиця 3

Динаміка експортно-імпортних операцій зерна, зернових та хлібних продуктів, млн. дол. США*

\begin{tabular}{|c|c|c|c|c|c|c|c|c|c|}
\hline \multirow{2}{*}{$\begin{array}{c}\text { Код і назва товарів згідно з } \\
\text { УКТЗЕД }\end{array}$} & \multicolumn{7}{|c|}{ Роки } & \multicolumn{2}{|c|}{2016 р у \% до } \\
\hline & 2008 & 2011 & 2012 & 2013 & 2014 & 2015 & 2016 & 2008 & 2015 \\
\hline \multicolumn{10}{|c|}{ ЕКСПОРТ } \\
\hline $\begin{array}{l}\text { II. Продукти рослинного по- } \\
\text { ходження }\end{array}$ & 5577 & 5532 & 9214 & 8876 & 8736 & 7971 & 8094 & 145 & 102 \\
\hline 10 Зернові культури & 3704 & 3617 & 7000 & 6371 & 6544 & 6057 & 6074 & 164 & 100 \\
\hline у \% до групи II & 66,4 & 65,4 & 76,0 & 71,8 & 74,9 & 76,0 & 75,0 & $\mathrm{X}$ & $\mathrm{X}$ \\
\hline 11. Продукція БКП** & 180 & 111 & 105 & 137 & 124 & 118 & 139 & 77 & 118 \\
\hline у\% до групи II & 3,2 & 2,0 & 1,1 & 1,5 & 1,4 & 1,5 & 1,7 & $X$ & $X$ \\
\hline IV. Готові харчові продукти & 2518 & 2939 & 3494 & 3557 & 3096 & 2468 & 2450 & 97 & 99 \\
\hline $\begin{array}{l}\text { 19. Продукти із зернових куль- } \\
\text { тур }\end{array}$ & 246 & 339 & 377,5 & 413,1 & 390,1 & 300,6 & 212,5 & 86 & 71 \\
\hline y\% до групи $I V$ & 9,8 & 11,5 & 10,8 & 11,6 & 12,6 & 12,2 & 8,7 & $\mathrm{X}$ & $\mathrm{X}$ \\
\hline $\begin{array}{l}\text { 1905.Хлібобулочні, борошняні } \\
\text { кондитерські вироби }\end{array}$ & 203,2 & 281,3 & 306,1 & 318,4 & 220,5 & 128,0 & 111,5 & 55 & 87 \\
\hline y\% до підгрупи 19 & 82,6 & 83,0 & 81,1 & 77,1 & 56,5 & 42,6 & 52,5 & $\mathrm{X}$ & $\mathrm{X}$ \\
\hline y\% до групи IV & 8,1 & 9,6 & 8,8 & 9,0 & 7,1 & 5,2 & 4,6 & $\mathrm{X}$ & $\mathrm{X}$ \\
\hline $\begin{array}{l}\text { 19012. Суміші та тісто для ви- } \\
\text { робництва х/б виробів товар- } \\
\text { ної позиції } 1905\end{array}$ & 0,1 & 2,1 & 2,5 & 2,3 & 2,0 & 1,2 & 1,0 & $11 \mathrm{p}$. & 85 \\
\hline \multicolumn{10}{|c|}{ IMПOPT } \\
\hline $\begin{array}{l}\text { II. Продукти рослинного по- } \\
\text { ходження }\end{array}$ & 1462 & 1816 & 2430 & 2670 & 2032 & 1146 & 1285 & 88 & 112 \\
\hline 10 Зернові культури & 147 & 220 & 249 & 307 & 367 & 155 & 149 & 102 & 96 \\
\hline y\% до групи II & 10,0 & 12,1 & 10,3 & 11,5 & 18,0 & 13,5 & 11,6 & $\mathrm{X}$ & $\mathrm{X}$ \\
\hline 11. Продукція БКП & 49 & 50 & 28 & 26 & 25 & 14 & 22 & 45 & 158 \\
\hline y\% до групи II & 3,3 & 2,7 & 1,2 & 1,0 & 1,2 & 1,2 & 1,7 & $\mathrm{X}$ & $\mathrm{X}$ \\
\hline IV. Готові харчові продукти & 2679 & 3027 & 2965 & 3219 & 2602 & 1608 & 1734 & 65 & 108 \\
\hline $\begin{array}{l}\text { 19. Продукти із зернових куль- } \\
\text { тур }\end{array}$ & 154 & 165 & 171 & 216 & 169 & 99 & 88 & 57 & 90 \\
\hline y\% до групи IV & 5,7 & 5,5 & 5,8 & 6,7 & 6,5 & 6,1 & 5,1 & $\mathrm{X}$ & $\mathrm{X}$ \\
\hline $\begin{array}{l}\text { 1905.Хлібобулочні, борошняні } \\
\text { кондитерські вироби }\end{array}$ & 65,3 & 74,2 & 60,8 & 78,6 & 60,2 & 26,7 & 26,0 & 40 & 97 \\
\hline y\% до підгрупи 19 & 42,4 & 45,0 & 35,6 & 36,4 & 35,6 & 27,0 & 29,4 & $\mathrm{X}$ & $\mathrm{X}$ \\
\hline y\% до групи IV & 2,4 & 2,5 & 2,1 & 2,4 & 2,3 & 1,7 & 1,5 & $\mathrm{X}$ & $\mathrm{X}$ \\
\hline $\begin{array}{l}\text { 19012. Суміші та тісто для ви- } \\
\text { робництва х/б виробів товарної } \\
\text { позиції } 1905\end{array}$ & 4,2 & 3,9 & 4,7 & 6,5 & 5,5 & 3,6 & 3,1 & 74,3 & 86,3 \\
\hline \multicolumn{8}{|c|}{ САЛЬДО (+, -) } & \multicolumn{2}{|c|}{$(+,-)$} \\
\hline $\begin{array}{l}\text { II. Продукти рослинного по- } \\
\text { ходження }\end{array}$ & 3875 & 3716 & 6784 & 6206 & 6704 & 6825 & 6809 & 2934 & -16 \\
\hline 10 Зернові культури & 3557 & 3397 & 6751 & 6065 & 6178 & 5903 & 5925 & 2368 & 22 \\
\hline 11. Продукція БКП & 131 & 62 & 77 & 111 & 99 & 104 & 117 & -15 & 13 \\
\hline IV. Готові харчові продукти & -161 & -88 & 529 & 338 & 495 & 861 & 716 & 877 & -145 \\
\hline $\begin{array}{l}\text { 19. Продукти із зернових куль- } \\
\text { тур }\end{array}$ & 92 & 174 & 207 & 197 & 221 & 202 & 124 & 32 & -78 \\
\hline $\begin{array}{l}\text { 1905.Хлібобулочні, борошняні } \\
\text { кондитерські вироби }\end{array}$ & 138 & 207 & 245 & 240 & 160 & 101 & 86 & -52 & -16 \\
\hline $\begin{array}{l}\text { 19012. Суміші та тісто для ви- } \\
\text { робництва х/б виробів товарної } \\
\text { позиції } 1905\end{array}$ & $-4,1$ & $-1,9$ & $-2,2$ & $-4,2$ & $-3,5$ & $-2,4$ & $-2,1$ & 2,0 & 0,3 \\
\hline
\end{tabular}

"Розраховано авторами за даними Держстату України [15]; ${ }^{* * *}$ БКП - борошномельно-круп’яна продукція. 
Таблиця 4

Динаміка та видова структура експорту хлібопродуктів з України"

\begin{tabular}{|c|c|c|c|c|c|c|c|c|c|}
\hline \multirow{2}{*}{$\begin{array}{c}\text { Код } \\
\text { УКТЗЕД }\end{array}$} & \multirow{2}{*}{$\begin{array}{l}\text { Види продукції за } \\
\text { УКТЗЕД }\end{array}$} & \multicolumn{7}{|c|}{ Роки } & \multirow{2}{*}{$\begin{array}{l}2016 \text { p. у \% } \\
\text { до } 2008 \text { p. }\end{array}$} \\
\hline & & 2008 & 2011 & 2012 & 2013 & 2014 & 2015 & 2016 & \\
\hline \multicolumn{10}{|c|}{ Експорт, тис. т } \\
\hline 19051 & Хрусткі хлібці & - & 0,018 & 0,012 & 0,030 & 0,005 & 0,004 & 0,010 & - \\
\hline 19052 & Пряники & 2,5 & 2,4 & 1,8 & 1,9 & 2,0 & 2,9 & 2,9 & 117 \\
\hline 190531 & Печиво солодке сухе & 77,5 & 92,3 & 89,4 & 86,9 & 57,5 & 44,3 & 40,6 & 52 \\
\hline 190532 & Вафлі та вафельні облатки & 15,0 & 21,9 & 22,3 & 21,0 & 17,9 & 15,2 & 14,9 & 99 \\
\hline 19054 & $\begin{array}{l}\text { Сухарі, грінки та аналогіч- } \\
\text { ні вироби }\end{array}$ & 2,8 & 4,0 & 5,6 & 6,7 & 8,1 & 9,0 & 5,8 & 208 \\
\hline 19059 & Інші & 27,2 & 32,6 & 39,9 & 44,8 & 32,4 & 18,7 & 19,3 & 71 \\
\hline & Усього & 125,0 & 153,3 & 159,1 & 161,3 & 117,8 & 90,0 & 83,5 & 67 \\
\hline \multicolumn{9}{|c|}{ Структура експорту, \% } & $(+,-)$ \\
\hline 19051 & Хрусткі хлібці & - & 0,01 & 0,01 & 0,02 & - & - & 0,01 & 0,01 \\
\hline 19052 & Пряники & 2,0 & 1,6 & 1,2 & 1,2 & 1,7 & 3,2 & 3,5 & 1,5 \\
\hline 190531 & Печиво солодке сухе & 62,0 & 60,2 & 56,2 & 53,9 & 48,8 & 49,2 & 48,6 & $-13,4$ \\
\hline 190532 & Вафлі та вафельні облатки & 12,0 & 14,3 & 14,0 & 13,0 & 15,2 & 16,9 & 17,8 & 5,8 \\
\hline 19054 & $\begin{array}{l}\text { Сухарі, грінки та аналогіч- } \\
\text { ні вироби }\end{array}$ & 2,2 & 2,6 & 3,5 & 4,1 & 6,8 & 9,9 & 7,0 & 4,8 \\
\hline 19059 & Інші & 21,8 & 21,3 & 25,1 & 27,8 & 27,5 & 20,7 & 23,1 & 1,3 \\
\hline
\end{tabular}

* Розраховано авторами за даними Державної служби статистики України [15]

Необхідно відзначити, що квоти на безмитний експорт до країн Свросоюзу хлібопродуктів тривалого зберігання за УКТЗЕД 1905 не передбачено. Відповідно до Угоди про ЗВТ, для продуктів із зернових культур (підгрупа 19) квоти на безмитний експорт передбачено для товарних груп 1903 «Тапіока та iii замінники у формі пластівців» і 1904 «Готові харчові вироби, одержані шляхом здуття або смаження зерна»; їх сукупний обсяг складає всього 2000 т. У 2016 р. вітчизняні експортери вичерпали всього 2,7 \% даної квоти [20], тобто експортували до країн СС 54 т. продукції. Для порівняння: у 2016 р. обсяг безмитного експорту пшениці склав 950 тис. т (100\% використання квоти) [20]. Наведені співвідношення $\epsilon$ свідченням, з одного боку, низьких обсягів безмитних квот та рівня їх використання для зернових продуктів iз високою доданою вартістю, з іншого, високих тех- нічних бар'єрів і невирішеності проблем у сфері технічного регулювання продукції.

Починаючи з 2013 р., імпорт хлібопродуктів в Україну скорочується (таблиця 5). У 2016 р. його обсяги в натуральному виразі склали 9,93 тис. т, зменшившись порівняно з 2008 р. на $58 \%$. У звітному періоді темп скорочення імпорту хлібної продукції (58 \%) є вищим темпу скорочення обсягів їі експорту (33\%). В останні роки імпорт хлібопродуктів досягає близько 3 \% від їх виробництва. У товарній структурі імпорту домінують інші вироби з часткою 65,7 \% в 2016 р.; друге місце займає печиво із питомою вагою $17,9 \%$, третє - вафлі із часткою 9,2\%. У географічній структурі імпорту хлібопродуктів в 2016 р. лідирують Польща (29\%), Німеччина $(15,9 \%)$ і Болгарія $(15,2 \%)$ [15].

Таблиця 5

Динаміка та видова структура імпорту хлібопродуктів в Україну“

\begin{tabular}{|c|c|c|c|c|c|c|c|c|c|}
\hline \multirow{2}{*}{$\begin{array}{c}\text { Код } \\
\text { УКТЗЕД }\end{array}$} & \multirow{2}{*}{$\begin{array}{c}\text { Види продукції за } \\
\text { УКТЗЕД }\end{array}$} & \multicolumn{7}{|c|}{ Роки } & \multirow{2}{*}{$\begin{array}{c}2016 \text { p. y \% } \\
\text { до } 2008 \text { р. }\end{array}$} \\
\hline & & 2008 & 2011 & 2012 & 2013 & 2014 & 2015 & 2016 & \\
\hline \multicolumn{10}{|c|}{ Імпорт, тис. т } \\
\hline 19051 & Хрусткі хлібці & 0,31 & 0,35 & 0,44 & 0,58 & 0,36 & 0,18 & 0,09 & 27,7 \\
\hline 19052 & Пряники & 0,03 & 0,10 & 0,11 & 0,14 & 0,07 & 0,03 & 0,06 & 223,1 \\
\hline 190531 & Печиво солодке сухе & 4,11 & 3,76 & 5,52 & 6,94 & 5,26 & 2,22 & 1,78 & 43,3 \\
\hline 190532 & $\begin{array}{l}\text { Вафлі та вафельні } \\
\text { облатки }\end{array}$ & 1,86 & 1,95 & 2,18 & 3,44 & 3,17 & 2,10 & 0,92 & 49,2 \\
\hline 19054 & $\begin{array}{l}\text { Сухарі, грінки та ана- } \\
\text { логічні вироби }\end{array}$ & 0,68 & 0,47 & 0,65 & 0,74 & 0,92 & 0,26 & 0,56 & 83,2 \\
\hline 19059 & Інші & 16,67 & 15,76 & 9,93 & 12,02 & 9,26 & 6,08 & 6,53 & 39,2 \\
\hline \multicolumn{2}{|r|}{ Усього } & 23,65 & 22,40 & 18,82 & 23,86 & 19,04 & 10,87 & $\mathbf{9 , 9 3}$ & 42,0 \\
\hline
\end{tabular}


Продовження табл.5

\begin{tabular}{|c|l|c|c|c|c|c|c|c|c|}
\hline \multicolumn{9}{|c|}{ Структура імпорту, \% } & $(+,-)$ \\
\hline 19051 & Хрусткі хлібці & 1,3 & 1,6 & 2,3 & 2,4 & 1,9 & 1,7 & 0,9 & $-0,4$ \\
\hline 19052 & Пряники & 0,1 & 0,5 & 0,6 & 0,6 & 0,4 & 0,3 & 0,6 & 0,5 \\
\hline 190531 & Печиво солодке сухе & 17,4 & 16,8 & 29,3 & 29,1 & 27,6 & 20,4 & 17,9 & 0,5 \\
\hline 190532 & $\begin{array}{l}\text { Вафлі та вафельні } \\
\text { облатки }\end{array}$ & 7,9 & 8,7 & 11,6 & 14,4 & 16,7 & 19,4 & 9,2 & 1,4 \\
\hline 19054 & $\begin{array}{l}\text { Сухарі, грінки та ана- } \\
\text { логічні вироби }\end{array}$ & 2,9 & 2,1 & 3,4 & 3,1 & 4,8 & 2,4 & 5,7 & 2,8 \\
\hline 19059 & Інші & 70,5 & 70,4 & 52,8 & 50,4 & 48,6 & 55,9 & 65,7 & $-4,7$ \\
\hline
\end{tabular}

* Розраховано авторами за даними Державної служби статистики України [15]

У вартісному виразі імпорт хлібопродуктів в Україну в 2016 р. склав 26 млн. дол. (29,4 \% до підгрупи 19 «Продукти із зернових культур), зменшившись порівняно 32008 р. на $60 \%$. За 2008-2016 pр. сальдо зовнішньої торгівлі хлібопродуктами є позитивним. Водночас якщо у 2008-2014 рр. сума сальдо за підгрупою 1905 в два і більше разів перевищувала суму сальдо підгрупи 11 «Борошномельно-круп'яна продукція», то в 2015-2016 рр. спостерігається зворотна тенденція (див. табл. 3). Таке співвідношення свідчить про зміну товарної структури вітчизняного продовольчого експорту шляхом скорочення експорту хлібної продукції з високою доданою вартістю.

Український ринок хлібопродуктів інтегрований до глобального хлібного ринку, пов'язаний із ним прямими й зворотними зв'язками, гнучко реагує на світові тенденції. Ринки хлібопродуктів окремих країн $є$ локальними ринками по відношенню до глобального хлібного ринку. Дане твердження підтверджує товарна диференціація ринків, унікальність попиту й пропозиції хлібних ринків окремих країн, що є однією з ознак локального ринку. Так, найбільш поширеним видом хлібної продукції в Нідерландах є тигровий хліб, Ірландії - бармбрек, Грузії - шоті, Індії - чапаті, Китаї - маньтоу, Мексиці - тортилья, Австралії - дампер, Японії - шокупан, Болівії - куна- пи і т.д [18]. Глокалізація державних хлібних ринків полягає в розширенні традиційного асортименту за рахунок продукції інших країн з її адаптацією до місцевого попиту. Іншим напрямом глокалізації є збільшення асортиментного ряду хлібопродуктів тривалого зберігання для їх реалізації на зовнішніх ринках. Відтак, передумовою глокалізації державних хлібних ринків $є$ розширення їх товарних і географічних меж, їх взаємопроникнення в глобальний ринковий просTip.

Обсяг світового ринку хлібопродуктів у 2015 р. склав 53,56 млрд. дол. (23,47 млн. т), 3 них $56 \%$ або майже 30 млрд. дол. (10,75 млн. т) припадає на хлібобулочні вироби За звітний рік обсяг світового ринку пшеничного борошна досягнув 5,05 млрд. дол. (12,75 млн. тонн) і склав 27,9 \% обсягів глобального ринку борошномельно-круп'яної продукції у вартісному виразі (таблиця 6). Найбільш розвиненими $\epsilon$ хлібні ринки Західної Свропи та США; вони характеризуються високим ступенем насичення і низькою швидкістю зростання або навіть скороченням обсягів. Західна Європа має найбільший ринок у вартісному виразі, лідером за обсягами є Африка та Близький Схід, а лідерами за темпами зростання обсягів є Китай, Індія та В'єтнам [21].

Обсяг світового ринку зернових і хлібних продуктів *

Таблиця 6

\begin{tabular}{|l|c|c|c|}
\hline \multicolumn{1}{|c|}{ Види продукції } & $\begin{array}{c}\text { Обсяг ринку, } \\
\text { млн. дол. }\end{array}$ & $\begin{array}{c}\text { Обсяг ринку, } \\
\text { тис. т. }\end{array}$ & $\begin{array}{c}\text { Середня ціна, } \\
\text { дол./т }\end{array}$ \\
\hline $\begin{array}{l}\text { 1. Борошномельно-круп'яна продукція } \\
\text { (БКП), всього }\end{array}$ & 18064 & 35287 & 512 \\
\hline у т.ч. борошно пшеничне & 5048 & 12751 & 396 \\
\hline у\% до БКП & 27,9 & 36,1 & 77,3 \\
\hline $\begin{array}{l}\text { 2. Готові продукти із зернових культур, } \\
\text { всього }\end{array}$ & 53555 & 23465 & 2282 \\
\hline у т. ч. хлібобулочні вироби & 29974 & 10750 & 2788 \\
\hline у\% до готових продуктів & 56,0 & 45,8 & 122,2 \\
\hline
\end{tabular}

* Розраховано авторами за даними аналітичних видань [21]

Загалом на світовому ринку хлібопродуктів провідні позиції займають розвинені країни Європи -
Німеччина, Бельгія, Італія, Франція, а також Канада й США. При цьому Сполучені Штати, займаючи третє 
місце у світі за обсягами експорту хлібобулочних виробів (1,98 млрд. дол. у 2015 р.), є також найбіль- шим світовим імпортером хлібопродуктів (загальний обсяг імпорту перевищує 4 млрд. дол.) (таблиця 7).

Таблиця 7

Головні світові експортери та імпортери хлібобулочних виробів

\begin{tabular}{|l|c|c|l|c|c|}
\hline \multirow{2}{*}{ Головні експортери } & \multicolumn{2}{|c|}{ Експорт } & \multirow{2}{*}{ Головні імпортери } & \multicolumn{2}{c|}{ Імпорт } \\
\cline { 2 - 3 } & Млн. дол. & $\%$ & & Млн. дол. & $\%$ \\
\hline 1. Німеччина & 3457 & 19,1 & 1. США & 4041 & 24,9 \\
\hline 2. Канада & 2038 & 11,2 & 2.Великобританія & 2419 & 14,9 \\
\hline 3.США & 1984 & 10,9 & 3.Франція & 2153 & 13,3 \\
\hline 4. Бельгія & 1967 & 10,8 & 4.Німеччина & 1987 & 12,2 \\
\hline 5. Італія & 1910 & 10,5 & 5.Канада & 1459 & 9,0 \\
\hline 6. Франція & 1787 & 9,9 & 6.Голландія & 1015 & 6,3 \\
\hline 7. Голландія & 1610 & 8,9 & 7.Бельгія & 977 & 6,0 \\
\hline 8. Великобританія & 1262 & 7,0 & 8.Італія & 829 & 5,1 \\
\hline 9. Польща & 1205 & 6,6 & 9.Китай & 679 & 4,2 \\
\hline 10. Туреччина & 915 & 5,0 & 10.Іспанія & 669 & 4,1 \\
\hline Усього & 18135 & 100,0 & Усього & 16228 & 24,9 \\
\hline
\end{tabular}

*Розраховано авторами за даними аналітичних видань [21]

У звітному році головними світовими експортерами хлібопродуктів були Німеччина, Канада та США; їх частки у загальному обсязі експорту десяти країн-лідерів склали, відповідно, 19,1\%, 11,2\% і $10,9 \%$ (див. табл. 7). Водночас основними імпортерами хлібної продукції стали США, Великобританія та Франція із частками $24,9 \%, 14,9$ \% і 13,3 \% відповідно.

Висновки та перспективи подалыших досліджень. У ході дослідження шляхом декомпозиції та аналізу компонентів визначено теоретичну сутність категорії «ринкова глокалізація», обгрунтовано доцільність їі використання для характеристики сучасних процесів синтезу локалізації й глобалізації товарних ринків. Показано взаємозв'язок глокалізації з процесами ринкової інтеграції та дезінтеграції, виділено дві iii форми (внутрішню й зовнішню) та досліджено сучасні тенденції глокалізації на прикладі ринків зернових і хлібних продуктів. Характерними рисами «макролокалізації» Одеського ринку даних товарів, що проявляється на практиці як міжрегіональна інтеграція, $є$ такі:

1) розширення меж локального ринку за рахунок суміжних областей, його гнучкість, відкритість та міжрегіональний характер;

2) посилення ролі та стабілізуючої функції Одеського ринку в розвитку зернопереробного комплексу Причорноморського макрорегіону, що гальмує темпи скорочення обсягів випуску продукції (ї рівень $є$ нижчим середнього рівня в державі).

На підставі емпіричних досліджень до характерних тенденцій зовнішньої глокалізації українського ринку хлібопродуктів віднесемо наступні:

1) розширення товарних меж хлібного ринку за рахунок появи продуктів тривалого зберігання 3 унікальними властивостями та їх експорту i, як наслідок, розширення географічних меж локального ринку, його інтеграція в світовий ринковий простір;
2) значний трансформаційний вплив структурних змін світової торгівлі на експорт вітчизняних хлібних продуктів, скорочення його обсягів в 20142016 рр., від'ємне сальдо за товарною групою хлібних напівфабрикатів, які мають істотний невикористаний експортний потенціал;

3) зменшення обсягів експорту й суми позитивного сальдо у міру збільшення ступеня переробки продукції у ланцюжку «зерно - борошномельнокруп'яна продукція - хлібна продукція» як свідчення домінуючої сировинної орієнтації агроекспорту та неефективного використання потужного економічного потенціалу українського зернопереробного комплексу.

В умовах стагнації глобального попиту на сировинні товари перед державою постає завдання модернізації інтеграційної політики у внутрішньому та зовнішньому вимірі для максимального використання переваг глокалізації за одночасної мінімізації їі негативних ефектів. Акценти внутрішньої інтеграційної політики доцільно змістити на підтримку регіональних виробників якісних зерно- i хлібопродуктів, сприяти їм у сертифікації для експорту до ЄС та інших країн потенційно конкурентоспроможних товарів (до них належить і оброблена продукція зернових $[18$, c. 104]).

Вектор зовнішньої інтеграційної політики держави доцільно спрямувати на реалізацію експортного потенціалу вітчизняних хлібопродуктів 3 високою доданою вартістю шляхом зміцнення позицій експортерів на традиційних і освоєння нових зовнішніх ринків. Проблема якості й безпечності хлібної продукції, витоки якої беруть початок у «тінізації» внутрішніх ринків борошна й ХХБВ, стає одним із головних стримуючих чинників експорту українських хлібопродуктів. Ї̈̈ вирішення знаходиться у площині інституційної модернізації, системності впровадження та збалансування внутрішньої й зовнішньої ком 
понент інтеграційної політики держави в умовах глокалізації ринків.

Наукова новизна проведеного дослідження полягає в обгрунтуванні доцільності використання категорії «ринкова глокалізація» для оцінки взаємодій сучасних процесів локалізації й глобалізації товарних ринків, їх зв'язку з економічною інтеграцією й дезінтеграцією товарно-фінансових потоків ринків, а також в розвитку методичних підходів до аналізу процесів глокалізації на прикладі ринків зернових і хлібних продуктів. Теоретичне значення результатів дослідження полягає в розвитку концептуальних положень локалізації та інтеграції товарних ринків, практичне значення визначається можливістю використання науково-прикладних розробок державними органами влади в ході обгрунтування векторів внутрішньої й зовнішньої інтеграційної політики в ринковому вимірі. Перспективи подальших досліджень полягають в оцінці характерних рис і проявів глокалізації стратегічних агропродовольчих ринків країни 3 використанням наукових підходів, висвітлених у даній статті.

\section{Література}

1. Прудніков Ю. В. Локальні ринки сільськогосподарської продукції / Ю.В.Прудніков // Інноваційна економіка. - 2014. - №6 (55). - С. 255-260.

2. Robertson Roland. Globalization: Social Theory and Global Culture / Roland Robertson // SAGE Publications, 1992. Printed in GreatiSritain by The Cromwell Press Ltd, Broughton Gifford, Melksham, Wiltshire. $306 \mathrm{p}$.

3. Khondker H. Globalization theory: A critical analysis. / H. Khondker. - National University of Singapore: Department of Sociology Working Paper, $1994-123$ p.

4. Giddens A. Runaway World. New York, 2000. -255 p.

5. Осташко Т. О. Зміна традиційних позицій українського експорту / Т. О. Осташко, В. Е. Лір, В.В. Венгер та ін. // Економіка і прогнозування. - 2017. - №2. - С. 57-74.

6. Нікішина О.В. Взаємодія процесів локалізації й глобалізації товарних ринків / О. В. Нікішина // Стратегії сталого розвитку: Х наук.-практ. конф., НІ «Універсум», 08 вересня 2017 р.: тези допов. - Вінниця: ТОВ «Нілан-ЛТД», 2017. - С. 57-61.

7. Nikishina O. V. Modern vectors of interregional market integration (on the example of Odessa market of grain and bread products) / O. V. Nikishina // Economy in 2018: XIV Scientific and Practical Conference, January 12, 2018: theses report. - Vinnitsa: LLC «Nilan-Ltd», 2018. - P. 81-85.

8. Власов В. В. О трактовании понятий «региональный» и «локальный» рынок / В. В. Власов // Социально-экономические явления и процессы. - 2011. - №11(033). - С. 56-59.

9. Екимова К. В. Локальные рынки в структуре региональной экономики / К. В. Екимова, С. В. Буравова, И. П. Савельева // Вестник ЮУрГУю. - 2011. - №41. - С.14-18.

10. Novicova N. V. Conceptual and terminological framework of the local consumer market research. Retrieved from: http://municipal.uapa.ru/en/issue/2012/01/04/

11. Ступникова А. В. Теоретические аспекты формирования и функционирования локальних рынков / А. В. Ступникова // Проблемы современной экономики. - 2013. - №2 (46). - С. 70-72.

12. Краткий словарь современных понятий и терминов / Под общ. ред. В. А. Макаренко. - [3-е изд.]. М.:Республика, 2000. - 509 с.

13. Гальперин В. М. Микроэкономика: в 2 т. / В. М. Гальперин, С. М. Игнатьев, В. И. Моргунов. - СПб.: Экономическая школа, 1998. - Т. 2. - 1998. - 503 с.

14. Авдокушин Е. Ф. Некоторые особенности процесса глокализации мировой экономики. [Электронный ресурс] - Режим доступа: http://www.nitpa.org/nekotorye-osobennosti-processa-glokalizacii-mirovoj-ekonomikie-f-avdokushin-3/

15. Офіційний сайт Державної служби статистики України. [Електронний ресурс] - Режим доступу: http://www.ukrstat.gov.ua/

16. Офіційний сайт Головного управління статистики в Одеській області. [Електронний ресурс]. - Режим доступу: http://www.od.ukrstat.gov.ua/

17. Нікішина О. В. Інтеграційні тенденції й механізми розвитку українського ринку хліба та хлібобулочних виробів /О.В. Нікішина, Н. О. Бібікова // Економіка харчової промисловості. - 2018. - Т.10, Вип. 1. C. 24-35; DOI: 10.15673/fie.v10i1.862

18. Акинфиева И. Украинская булка на европейском столе / Ирина Акинфиева // Продукты@Ингредиенты. - 2010. - № 10. - С. 16 - 18.

19. Осташко Т. О. Можливості та обмеження експорту сільськогосподарських товарів у зоні тарифних квот ЄС / Т. О. Осташко // Стратегічні пріоритети. - 2016. - №1 (38). - С. 99-105. 
20. Офіційний сайт Інформаційного Агентства УНІАН: Україна в 2016 р. повністю вичерпала квоти на безмитний експорт до $\mathrm{C} \mathrm{за} 11$ групами товарів. [Електронний ресурс]. - Режим доступу: https://www.unian.ua/eurobusiness/1731212-ukrajina-v-2016-rotsi-povnistyu-vicherpala-kvoti-na-bezmitniy-eksportdo-es-za-11-grupami-tovariv.html

21. World market of bread and flour confectionery. Retrieved 2017 from http://www.breadbranch.com/magazine/archive/viewdoc/2011/12/1095.html

Стаття надійшла 12.04.2018 Стаття прийнята до друку 26.04.2018 Доступно в мережі Internet 7.07.2018

\author{
Никишина О.В. \\ доктор экономических наук, старший научный сотрудник \\ E-mail: ksenkych@gmail.com \\ Зарудная О. П. \\ аспирант \\ отдел рыночных механизмов и структур \\ Институт проблем рынка и экономико-экологических исследований НАН Украины \\ Французский бульвар, 29, г.Одесса, Украина, 65044 \\ E-mail: zarudnayaolya@ukr.net
}

\title{
ГЛОКАЛИЗАЦИЯ ТОВАРНЫХ РЫНКОВ: ТЕОРЕТИЧЕСКИЕ И ПРИКЛАДНЫЕ АСПЕКТЫ
}

В современных условиях развитие рыночных систем характеризуется одновременно двумя противодействующими тенденциями: глобализацией и локализацией. Актуальность исследования и оценки современных процессов глокализации товарных рынков обусловлена необходимостью формирования научно-аналитической базы для разработки новой интеграционной политики государства во внутреннем и внешнем измерении, а также для обоснования внешнеэкономических приоритетов развития страны в условиях открытой экономики.

Целью статьи является определение теоретической сущности глокализации товарных рынков и ее современных тенденций на примере украинских рынков зерновых и хлебных продуктов. В ходе исследования использованы следующие методы: диалектика, структурно-динамический анализ, горизонтальный и вертикальный сравнительный анализ.

В статье авторами путем декомпозиции и анализа компонентов определена природа категории «рыночная глокализация», показана ее взаимосвязь с процессами рыночной интеграции и дезинтеграции. Выделены две фрормы глокализации - внутреннюю и внешнюю, исследованы современные тенденции глокализации на примере украинских рынков зерновых и хлебных продуктов. Сделан вывод о межрегиональной интеграции одесского рынка, расширении границ локального рынка, его стабилизирующей функции в развитии зерноперерабатывающего комплекса Причерноморского региона. Показаны векторы и проблемы внешней глокализации внутреннего рынка хлебопродуктов длительного хранения, акцентировано внимание на необходимости наращивания экспорта продуктов переработки.

Обоснованы направления модернизации государственной интеграционной политики во внутреннем и внешнем измерении. Акценты внутренней интеграционной политики целесообразно сместить в сторону поддержки региональных производителей качественных продуктов переработки, содействия им в сертификации товаров. Вектор внешней интеграционной политики целесообразно направить на укрепление позиций экспортеров продуктов переработки на внешних рынках, решение проблемы качества и безопасности хлебной продукции. Сделан вывод о необходимости сбалансирования внутренней и внешней компонент интеграционной политики для получения максимальных эффектов от глокализации товарных рынков.

Ключевые слова: локализация, товарный рынок, интеграция, глокализация, зерновые и хлебные продукты, экспорт, интеграционная политика государства. 


\section{Nikishina 0. \\ Doctor of Economics, Senior Researcher \\ E-mail: ksenkych@gmail.com \\ Zarudna 0. \\ Postgraduate \\ Department of Market Mechanisms and Structures \\ Institute of Market Problems and Economic \& Ecological Research \\ of National Academy of Sciences of Ukraine \\ Frantsuzskiy boulevard, 29, Odesa, Ukraine, 65044 \\ E-mail: zarudnayaolya@ukr.net \\ GLOBALIZATION OF COMMODITY MARKETS: THEORETICAL AND APPLIED ASPECTS}

In modern conditions, the development of market systems is characterized simultaneously by two opposite trends: globalization and localization. Relevance of the research and evaluation of modern processes of globalization of commodity markets is stipulated by necessity of formation scientific and analytical basis for the development of a modern integration policy in internal and external dimensions, as well as for substantiation of foreign economic priorities of the country development in the conditions of open economy.

The aim of the article is to determine the theoretical essence of globalization of commodity markets and its modern trends on the example of Ukrainian markets of grains and bakery products. In the research, the following methods are used: dialectics, structural and dynamic analysis, horizontal and vertical comparative analysis.

In the article the nature of the category «market globalization» has been determined authors by decomposition and component analysis, its interrelation with the processes of market integration and disintegration is shown. Two forms of globalization have been determined - internal and external, modern tendencies of globalization have been investigated on the example of Ukrainian markets of grains and bakery products. The conclusion has been made concerning interregional integration of Odessa market, expanding the limits of the local market, its stabilizing function in the development of grain processing complex in Black Sea region. Vectors and problems of external globalization of the domestic market of bakery products of long storage have been shown, the emphasis has been made on the need to increase the export of the processed products.

Conclusions. The directions of modernization of the state integration policy in the internal and external dimensions have been substantiated. The accents of internal integration policy are advisable to direct in support of regional producers of the qualitative processing products, facilitating them in certification of goods. The vector of the foreign integration policy is advisable to focus on strengthening positions of exporters of processed products in foreign markets, solution of the problem of quality and safety of cereal products. The conclusion has been made on the need for balancing the internal and external components of the integration policy for maximum effects from commodity market globalization.

Keywords: localization, commodity market, integration, globalization, grain and bakery products, export, integration policy of the state.

\section{References}

1. Prudnikov, Yu. V. (2014). Lokalni rynky silskohospodarskoi produktsii. Innovatsiina Ekonomika,(6(55)), 255-260.

2. Robertson, R. (1992). Globalization: Social Theory and Global Culture. Melksham, Wiltshire: Cromwell Press Ltd.

3. Khondker, H. (1994). Globalization theory: A critical analysis. Singapore: National University of Singapore: Department of Sociology Working Paper.

4. Giddens, A. (2000). Runaway World. New York.

5. Ostashko, T. O., Lir, V. E., \& Venher, V. V. (2017). Zmina tradytsiinykh pozytsii ukrainskoho eksportu. Ekonomika I Prohnozuvannia, (2), 57-74.

6. Nikishyna, O. V. (2017). Vzaiemodiia protsesiv lokalizatsii y hlobalizatsii tovarnykh rynkiv. In Stratehii staloho rozvytku (pp. 57-61). Vinnytsia: TOV «Nilan-LTD».

7. Nikishina, O. V. (2018). Modern vectors of interregional market integration (on the example of Odessa market of grain and bread products). In Economy in 2018 (pp. 81-85). Vinnitsa: LLC «Nilan-Ltd».

8. Vlasov, V. V. (2011). O traktovanii ponyatiy «regionalnyiy» $\mathrm{i}$ «lokalnyiy» ryinok. Sotsialno-ekonomicheskie Yavleniya I Protsessyi, (11(033)), 56-59. 
9. Ekimova, K. V., Buravova, S. V., \& Saveleva, I. P. (2011). Lokalnyie ryinki v strukture regionalnoy ekonomiki. Vestnik YuUrGUyu, (41), 14-18.

10. Novicova, N. V. (2012). Conceptual and terminological framework of the local consumer market research. Retrieved from http://municipal.uapa.ru/en/issue/2012/01/04/

11. Stupnikova, A. V. (2013). Teoreticheskie aspektyi formirovaniya i funktsionirovaniya lokalnih ryinkov. Problemyi Sovremennoy Ekonomiki, (2(46)), 70-72. publika.

12. Makarenko, V. A. (Ed.). (2000). Kratkiy slovar sovremennyih ponyatiy i terminov (3-e izd. ed.). M.: Res-

13. Galperin, V. M., Ignatev, S. M., \& Morgunov, V. I. (1998). Mikroekonomika (Vol. 2). SPb.: Ekonomicheskaya shkola.

14. Avdokushin, E. F. (2017, July 29). Nekotoryie osobennosti protsessa glokalizatsii mirovoy ekonomiki. Retrieved from http://www.nitpa.org/nekotorye-osobennosti-processa-glokalizacii-mirovoj-ekonomiki-e-f-avdokushin-3/

15. Ofitsiinyi sait Derzhavnoi sluzhby statystyky Ukrainy. (2018). Retrieved from http://www.ukrstat.gov.ua/

16. Ofitsiinyi sait Holovnoho upravlinnia statystyky v Odeskii oblasti. (2018). Retrieved from http://www.od.ukrstat.gov.ua/

17. Nikishyna, O. V., \& Bibikova, N. O. (2018). Intehratsiini tendentsii y mekhanizmy rozvytku ukrainskoho rynku khliba ta khlibobulochnykh vyrobiv. Ekonomika Kharchovoi Promyslovosti,10(1), 24-35.

doi:10.15673/fie.v10i1.862

18. Akinfieva, I. (2010). Ukrainskaya bulka na evropeyskom stole. Produktyi@Ingredientyi, (10), 16-18.

19. Ostashko, T. V. (2016). Mozhlyvosti ta obmezhennia eksportu silskohospodarskykh tovariv u zoni taryfnykh kvot YeS. Stratehichni Priorytety, (1(38)), 99-105.

20. Ukraina v 2016 r. povnistiu vycherpala kvoty na bezmytnyi eksport do YeS za 11 hrupamy tovariv. (2017, January 18). Retrieved from https://www.unian.ua/eurobusiness/1731212-ukrajina-v-2016-rotsi-povnistyu-vicherpalakvoti-na-bezmitniy-eksport-do-es-za-11-grupami-tovariv.html

21. World market of bread and flour confectionery. (2017). Retrieved from http://www.breadbranch.com/magazine/archive/viewdoc/2011/12/1095.html 